\title{
Reviewer Acknowledgements for Global Journal of Health Science, Vol. 10, No. 11
}

Global Journal of Health Science wishes to acknowledge the following individuals for their assistance with peer review of manuscripts for this issue. Their help and contributions in maintaining the quality of the journal are greatly appreciated.

Global Journal of Health Science is recruiting reviewers for the journal. If you are interested in becoming a reviewer, we welcome you to join us. Please find the application form and details at http://recruitment.ccsenet.org and e-mail the completed application form to gjhs@ccsenet.org.

\section{Reviewers for Volume 10, Number 11}

Abdulbari Bener, Istaanbul University, Turkey

Ama Pokuaa Fenny, University of Ghana, Ghana

Angel Alfonso Velarde Lopez, University of Pennsylvania, Guatemala

António Calha, Polytechnic Institute of Portalegre, Portugal

Ayesha Johnson, University of South Florida, United States of America

Basak Baglama, Near East University, Cyprus

Celia Moffat Joel Matyanga, Harare Institute of Technology, Zimbabwe

Chung-Yu Chen, Kaohsiung Medical University Hospital, Taiwan

Dilek Pirim, Uludag University, Turkey

Domitila Augusta Huber, Federal University of Santa Catarina, Brazil

Evanthia Sakellari, Technological Educational Institute of Athens, Greece

France Ncube, Bindura University of Science Education, Zimbabwe

Gabriele Messina, University of Siena, Italy

Georgann Valerie Weissman, Capella University, United States of America

Hadii M Mamudu, East Tennessee State University, United States of America

Hilal Hamood Alrahbi, Diwan of Royal Court-Oman, Oman

Hülya YARDIMCI, Ankara University, Turkey

Jaime Hinzpeter, Clinical Hospital University of Chile, Chile

Jan Chrastina, Palacký University, Czech Republic

Jason Tsai, Lincoln College, United Kingdom

Jingxian Cai, ICSA, ASA, ENAR, United States of America

Liye Suo, The Ohio State University, United States of America

Loray Daws, British Columbia Masterson Institute, Canada

Meng Zhao, Texas A\&M University at Corpus Christi, United States of America

Pi-Ming Yeh, Missouri Western State University, United States of America

Raúl Quevedo-Blasco, Universidad de Granada, Spain

Raywat Deonandan, University of Ottawa, Canada

Roger Ho, National University of Singapore, Singapore

Samir Othman, Hawler Medical University, Iraq

Thammanard Charernboon, Thammasat University, Thailand

Trisha Dunning, Deakin University and Barwon Health, Australia 